\title{
Divine Kingship in Medieval Sri Lanka \\ Dynamics in Traditions of Power and Virtue in South Asia
}

\author{
STEPHEN C. BERKWITZ \\ Missouri State University, United States
}

\begin{abstract}
The present article focuses on Sri Lankan views of divine kingship to illustrate how the figure of the king was developed in ways that borrowed and were shaped by the transfer of Hindu notions of kings and gods around the period of intensive Hindu interventions into the island from the tenth to thirteenth centuries CE. After discussing the paradigmatic figure of King Aśoka, the virtuous king (dhammaräja) held to be the model for all subsequent monarchs in the tradition, we will examine inscriptional and poetic writings that conflated Sri Lankan kings with Hindu gods. The dynamics of comparing kings with gods has ancient roots in India, and these notions were adopted by Sri Lankan Buddhists during the long "medieval" period of roughly the tenth to the sixteenth centuries CE. The dynamic introduction of new strands of Buddhist kingship expanded upon the figure of the king. I argue that this development was primarily metaphorical in nature, and it was further enhanced by eulogizing kings as bodhisattvas, or future Buddhas. By incorporating much of the language and notions of divine kingship from the Hindu tradition, Sri Lankan Buddhism made kingship into the dynamic site for cultural borrowing. Yet it stabilized and reinforced its local traditions by comparing kings with gods and bodhisattvas, presenting them as being like extraordinary beings in the context of praise for their power and virtue.
\end{abstract}

KEYWORDS Buddhism, Kingship, Aśoka, Gods, Poetry, Bodhisattva, Metaphor

\section{Introduction}

Scholarship on kingship in South Asia comprises numerous works that speak to the importance of kings in premodern political and religious thought. Much of this research focuses on the ancient Indian dynasties of the Mauryas and Guptas, among others, if not the kings mentioned in classical Hindu Epics. From Aśoka to Yudhișțira, and other kings in between, the power, charisma, and devotion of kings have long been a subject of recurrent scholarly investigation in the history and mythology of South Asia. Moreover, there has been no shortage of scholars who have studied the variant of Buddhist kingship in South Asia. The dominant model used for conceiving of Buddhist kingship has been that of King Aśoka, particularly as he appears 
as the righteous Universal Monarch (cakkavatti) in Sri Lankan vamsa (or "chronicle") texts. This selective image of a pious and powerful Buddhist ruler has proven to be paradigmatic for later kings and scholars alike.

And yet to the extent that Aśoka has shaped the images and ideals of Buddhist kingship, our understanding of what a supposedly "Buddhist king" is and does has been constructed in a partial and idealized manner. If we expand our attention to Buddhist kings beyond the vamsa literature, and examine inscriptions, chronicles, and poetry in Sinhala writings from roughly the tenth to sixteenth centuries $\mathrm{CE}$, new models of kingship emerge in the context of interreligious and intrareligious contacts among Buddhists and Hindus in South Asia. By highlighting the dynamics of South Asian expressions of kingship and the resulting development of a Buddhist version of "divine kingship", it will be possible to analyze a significant site for cultural encounters and religious exchange across traditions. This effort will enable us to conclude that there is no singular "Theravāda" theory of kingship, but rather a rich array of images and metaphors used to construct power and sovereignty in different historical circumstances. In other words, the idea of "Buddhist kingship" is a plural one that incorporated various religious and political traditions in various times and places. In a context where religious affiliations and identities were often blurred, notions of divine kingship similarly developed as hybrid politico-cultural forms. The present article will focus on Sri Lankan views of kingship to illustrate how the figure of the king was developed and represented in ways that borrowed from broadly speaking "Hindu" notions of kings and gods during and subsequent to the period of intensive Hindu interventions into the island from the tenth to the thirteenth centuries. The resulting notion of divine kingship, whereby Sri Lankan kings were creatively conflated with deities, appears as an interesting variant of a familiar Indological and anthropological construct, one that lays bare the entangled religions of South Asia in premodern eras.

Indeed, it seems likely that because the kingly role was not exclusive to any one religion and developed alongside ritual and doctrinal systems of several different traditions, Sinhala kingship in its material and conceptual forms could easily incorporate features from various Hindu and Buddhist traditions. In the ancient Indic civilizational sphere, more generally, kings alone could guarantee the protection of people through the upholding of dharma, although beyond this assumption there was no unified view of kingship in South Asia (Heesterman 1998, 14). It was widely assumed that a society without a king would be lost, and subject to decay and ruin. Kings were also understood to be the necessary basis for a peaceful, orderly society in ancient Sri Lanka (Ariyapala [1956] 1997, 45). But aside from that idea, Hindu and Buddhist kings were typically patterned after a number of different models, and there is evidence of inter-religious adaptation of royal roles, symbols, and titles from an early period. Phrased differently, notions of kingship in premodern South Asia formed a complex stew of ideas and images associated with sovereignty and divinity. It is thus necessary to complicate the picture of the so-called Buddhist king and move beyond a singular ideal for defining power and sovereignty in Buddhist traditions. As noted above, the paradigm of King Aśoka still looms large in scholarship on Buddhist kingship. Stanley Tambiah and others have set up Aśoka as the paradigmatic Buddhist ruler, whose reputation for propounding the Dharma both in terms of moral righteousness and support for the monastic community are said to have become something of a charter for other rulers to follow (Tambiah 1976, 57, 64-65). Kings emulating this model were not limited to Buddhists, either. Aśoka's model of universal 
kingship as a "Wheel-Turning Monarch," or cakravatin, in turn came to influence broader Hindu ideals of extensive sovereignty as well (Ali 2011, 93-94).

Even a passing acquaintance with Sinhala inscriptions and written works from the medieval period of Sri Lankan history will show that kings were depicted in a variety of ways, not all of which are derived straight from the image of the powerful and righteous King Aśoka. Instead, we find an expansion of Buddhist royal ideology in medieval Sri Lanka, a development that marks one of the key outcomes of the intensive encounters with South Indian Hindus due to warfare, migration, and trade between the tenth and thirteenth centuries in Sri Lanka. The peak of these exchanges occurred during the nearly eighty-years of Cōla occupation on the island during the eleventh century. The Cōlas came from Tamil-speaking lands in South India, and sought to expand their imperial hegemony in neighboring lands such as Sri Lanka to win honor, obtain plunder, and to keep potentially restless troops engaged in distant campaigns (Spencer 1983, 22-23). The long Cōla occupation in northern Sri Lanka had a destructive impact on the local Buddhist Sangha and temples in the short term, but it also occasioned greater cross-fertilization with Hindu rites and ideas over time. Śaiva shrines and brahmins had been imported and established in Sri Lanka during this period, and they persisted even after the Cōlas were forcibly driven from the island. Soldiers and scholars from South India were regularly patronized by Sri Lankan kings, with the effect of strengthening their armies and enriching the literary culture of the island's royal courts (Nicholas and Paranavitana 1961, 196-97).

These cultural flows back and forth across the Palk Strait ensured that a variety of Indic strands of kingship were introduced into Sri Lanka. These dynamics of cultural encounters and cultural exchange generated new models for enacting sovereignty through processes that involved both local inflection and trans-local imitation (Blackburn 2017, 73). Ideas and rites associated with Cōla kings, including divine kingship, eulogistic writing, and the abhișeka consecration, took on new significance in Sri Lanka, transforming what it meant to be a Buddhist king. Interactions with the Pallavas and other kingdoms in South India were also sites for enlarging local notions of kingship and sovereignty in Sri Lanka. Particularly central to these new formulations was the conflation of king and god in the representation of political and moral authority. Sri Lankan Buddhists eagerly adapted notions of divine kingship in an apparent effort to enhance the fame and power of their kings, in manners similar to predominantly Hindu communities in the Indian subcontinent.

\section{Divine Kings}

The attribution of divine kingship has had a long and varied history in South Asia. Vedic and other early Brahmanical sources describe kings as possessing components of deities and wielding extraordinary powers on behalf of the world and its inhabitants. Jan Gonda cites texts that describe the ancient Indic king as a deva, or "god among men," having been created from particles of Indra and other great deities that bestow upon him great power and majesty (Gonda 1966, 24-25). The king was seen as a mediator between the divine and human realms, a great being responsible for ordering society and insuring that life-giving rains fell when needed. The connections that Vedic poets established between Indra and human kings, as both were obliged to protect their subjects and to combat evil with their energy and power, become further enhanced in later writings that expressed the view that the king is Indra in visible form (Gonda 1966, 30; Shulman 1985, 93). Over time, Hindu kings began to adopt for 
themselves a purānic genealogy that linked them by birth to ancient heroes from epic texts and ultimately to the Sun and the Moon, which could indicate their power to regulate the seasons and other natural events (Scharfe 1989, 237). Their descent from these heroes and natural phenomena marked a short step to reaffirming their divine nature through a connection to the gods of classical Hinduism, such as Brahman and Viṣnu (Scharfe 1989, 237-38).

Thus, by the early medieval period following the Gupta Dynasty in India, Hindu kings were regularly attributed with a divine pedigree that reflected their extraordinary nature and empowered them to act in the world. Texts such as the Purānas and Dharmaśāastras affirmed that kings incorporate portions of the eight divine lokapalas, or "guardians of the world." These divinities comprise Sūrya, Candra, Vāyu, Yama, Agni, Kubera, Varuṇa, and Indra, and they collectively represent the various spheres of power wielded by kings and instantiated in their bodies to protect and order the world (Inden 1998, 48-49). The king's powers to illumine the world, provide food for his subjects, punish wrong-doers, and protect all those who reside in his kingdom were understood to originate in divine powers with which he was born. Such qualities make the king uniquely qualified to rule, and deserving of the same honor and esteem that is otherwise offered to the gods. The associations of lordship shared between kings and deities did not only imply overlapping spheres of command, but they also linked them together in what Ronald Inden has called the "Hindu Chain of Being" (Inden 1985a, 160-65). Indic kings were thus seen to embody aspects of divine power while being enmeshed in a cosmology that often placed kings in a mediating position between the gods and humans. Similar types of praise are found in later Tamil poems, where the genealogy of the king is typically traced back to Viṣnu, and the god's dark and regal appearance may also be compared with that of the king in question (Shulman 1985, 313-14).

It should be noted, however, that despite the evolving, influential theology of divine kingship in premodern India, there remained other views and models of sovereignty that shaped how Hindus imagined their kings. The ethical orientation of a self-disciplined, just, and generous king, a person trained in the sciences of kingship and devoted to räjadharma, or the "duty of kings," was a contribution of early Buddhist thought and other political theories, and this cluster of ideas continued to have influence in Indic courts (Ali 2011, 93-94). From this perspective, the Hindu king rules properly in accordance with the social and cosmic order of dharma as a result of the training and counsel he receives. From Kautilya's Arthaśāstra to the edifying tales of the Pañcatantra, there was no shortage of texts from which a king or his counselors could draw important lessons and advice for meeting with success in one's rule. Even in instances where a notion of "divine kingship" operated, this concept was subject to different interpretations. Among the Pallavas, for example, it could refer to the king's functional analogy to the gods, the king as the representative of god on earth, the king as a being who shares the identity of the supreme god, or the king as a liminal figure who exists between gods and humans (Francis 2013, 1:8-9). Overall, it is quickly apparent that there was no single theory of kingship in Hinduism, and that one must instead see the phenomenon as what Daud Ali describes as "a historically constituted and changing set of ideas and practices that must be placed against wider historical processes, social, economic, and religious" (Ali 2011, 90).

Of course, the same can (and should) be said about kingship in Buddhism. The following discussion will outline how the dynamics of cultural contact and transfer gave rise to different strands of kingship in medieval Sri Lanka, which in turn came to elaborate and enhance the notions of kingship and sovereignty in a culture where Buddhism held sway. The expansion 
of ideals associated with Buddhist kingship led to a certain stabilization of this royal position through the repeated recognition of multiple, quasi-divine kings that submitted themselves to Buddhist teachings and institutions, while being empowered by their apparent resemblances to deities. The brief review of ideas associated with Indic kingship will be helpful to situate the development and transformation of Buddhist ideas about kings between the tenth and sixteenth centuries in Sri Lanka, a period in which religious and cultural transfers increased due to the intensive contacts with Hindu soldiers, traders, priests, and scholars from the mainland. It was in this same period that Sri Lankan Buddhists adapted and transformed how their own traditions of kingship were understood and portrayed in connection with the ways that Indic authors depicted kings in literary forms such as inscriptional eulogies and aesthetically rich court poetry. New strands of kingship became interwoven with older Buddhist traditions about sovereignty, leading to the formation of new models for embodying and exercising power that resonated with notions of kingship in other lands. ${ }^{1}$

\section{Buddhist Kings in vamsa Texts}

One of the strands of "Buddhist kingship", or the dominant political mode in Sri Lanka wherein rulers associated themselves and their rules with the religion of the Buddha, was developed internally in Sri Lanka's own chronicle tradition of vamsa writing. These texts were called vamsas (meaning "lineage" or "bamboo") to foreground their interests in detailing the lineages of kings and monks that were deemed consequential for the history of Buddhism. Such works, including the sixth-century Mahāvamsa, related the stories of ancient kings and their deeds to promote the teachings and institutions founded by the Buddha (i.e., his sāsana). Not every king is celebrated in the folios of these vamsas, but those that are tend to embody the righteous "Dharmarāja" who acts like Aśoka to promote and purify the Buddha's religion on the island (Deeg 2016, 305). In this ancient period, two Sri Lankan Buddhist kings stand out in particular. King Devānampiya-tissa, a contemporary and ally of Aśoka, is lauded for welcoming Buddhist monks to the island and building shrines to the Bodhi Tree and other relics. The author of the Mahāvamsa asserts that Devānampiya-tissa's personal delight was in the blessing of the true teaching, and the text confirms that he built monasteries around Anuradhapura, the capital city of his kingdom (Geiger [1912] 2001, 136). The same text also celebrates the works of King Duțthagāmaṇi, who reigned in the second century BCE, for liberating the island from foreign occupiers and building more sites to promote the religion, such as the Great Relic Shrine (Mahāthūpa). Therein, this king is depicted as pious and generous, even being praised for renouncing rebirth in heaven to be reborn in the world, where he performed many acts of merit and brought glory to the Buddha's Dharma (Geiger [1912] 2001, 222). Not all kings receive significant attention and praise, but those that do generally conform to the conventional ideals of the office.

The praise given to such kings in the vamsa literature is instructive. Kings who are said to have imitated the righteous sovereignty of Aśoka by actively supporting and spreading the Buddha's religion receive abundant praise for their piety in these texts. Other kings who fail to meet this basic duty are denounced or disregarded. Later vamsa texts that focus on

1 It should be noted that Khmer Buddhists also had a notion of the divine king, or devaräja, in this period (Thompson 2016, 25-26). Although the Khmer devaräja had an influence on kingship in the Thai Ayutthaya kingdom, there is scant evidence to show that the Khmer model was operative in Sri Lanka during the medieval period (Tambiah 1976, 89-91). 
one or another relic in Sri Lanka also portray the great Buddhist kings of the past in a very positive light. Works such as the tenth-century Mahäbodhivamsa and the thirteenth-century Thūpavamsa both celebrate the righteous kings Aśoka, Devānampiya-tissa, and Duțthagāmaṇi for their diligent service to the religion and their personal devotion to the Triple Gem of the Buddha, Dharma, and Sangha. These royal figures are cast as historical actors that exemplify dharmarājas, or kings whose rule is devoted first and foremost to promoting the Buddha's Teachings. In part, given the outsized role that the vamsas assumed in narrating the history of Buddhism in Sri Lanka and elsewhere in mainland Southeast Asia, their depiction of celebrated Buddhist kings became normative for both the tradition and the scholars who study it. This tradition, which later becomes referred to as Theravāda Buddhism, equates itself with the oldest, most orthodox form of the Buddha's religion. While such a self-presentation effectively obscures the internal diversity and later developments to be found in this tradition, it nevertheless helps to explain why the image of the Buddhist dharmaräja tends to predominate in the narratives produced both within the tradition and outside it in Buddhist Studies scholarship.

And yet the traditions associated with the Theravāda monastic community and the Pālilanguage texts that remained central to its formation were not solely beholden to the vamsas for their portrayals of Buddhist kings. Assuredly, the image of a king who gives wealth to the Sangha, builds or repairs monasteries and ritual shrines, and provides for his subjects' needs remained an important index for sovereignty and authority in medieval Sri Lanka. The typical vamsa depiction of kingship called for kings to honor and occasionally purify the Sangha from internal corruption, as well as to rule in general with the welfare of the sāsana and its devotees always in mind. In the tenth to sixteenth centuries, however, Sri Lankan authors blended and expanded the dharmarāja image of kingship by incorporating other ideas and symbols of powerful kings that were circulating around South Asia. The tropes and images associated with divine kingship in Hindu polities made their presence felt in Indian courts and literature, both of which came to exert increasing influence in Sri Lankan circles at this time.

Sanskrit forms of court poetry, also known as kārya, portrayed gods as kinglike and kings as godlike, with both entities enjoying power and pleasure in the company of females (Smith 1985, 83). The conflation of kings and gods in literary culture was a key feature of what Sheldon Pollock calls the "Sanskrit Cosmopolis." Developing in the first millennium of the Common Era across Southern Asia, and increasingly taking vernacular forms at the start of the second millennium, the literary culture of royal inscriptions and court poetry promoted certain views of power that were concentrated in the figures of kings and poets (Pollock 2006, $67,114,136-37)$. While poets were held to possess the power to bring new things into being through their skillful use of language, kings were regularly lauded for their associations with divine power and majesty. This ideology, which enhanced the role and significance of kings, was primarily conveyed by the spread of Sanskrit literature across India and beyond to places like Sri Lanka. In this manner, kingship in Sri Lanka began to develop and transform along new lines, incorporating new models of divine Buddhist kings that emerged in the transfer of written texts and panegyric inscriptions celebrating their marvelous qualities. Among the Pāli texts that began to glorify kings in magnificent ways, the Cūlavamsa (or "Extended Mahāvamsa") occasionally marked out select kings for abundant, aesthetically rich praise. For example, Parākkamabāhu I (r. 1153-1186) is therein explicitly linked with the Solar dynasty, and is said to hold the entire world in his power through his own singular courage (Geiger 
1953a, 1:330-31). Similarly, a later chronicler lauds Parākkamabāhu VI (r. 1412-1467) as "an abode of wisdom and manly virtue, a scion of the race of the Sun" (Geiger 1953b, 2:215). Such instances of ornate praise in the Cūlavamsa reflect the rapid growth in eulogistic writing seen in Sinhala inscriptions from around the ninth century CE.

\section{Inscriptional Praise of Kings}

Sri Lanka's history of inscriptions is very old, with many inscriptions dating back before the beginning of the Common Era. Early inscriptions written in the Brāhmī script tend to be short, straightforward confirmations of gifts given to the Sangha. Over time, however, inscriptions became more elaborate and literary in nature, chiefly noting what kings gifted to the Sangha, Brahmin priests, courtiers, and various subjects. These inscriptions, typically written in Sinhala but evocative of the formal, obsequious style of Sanskrit praśasti writing, constructed new images of kingship in Sri Lanka by adapting many conventions from the mainland. This type of inscriptional praśasti writing in the form of royal edicts focused on providing an impressive genealogy of the king's lineage and an equally impressive cataloguing of the king's personal virtues. Many Sinhala inscriptions from the tenth century onwards contain genealogies that link the island's kings to the Sun and other mythical or legendary beings (Perera 2003, 2:4445). The claim of descent from the Sun matches up with those Hindu Purānas that identified past kings as coming from the Sun or Moon, which led many medieval royal dynasties to claim solar or lunar origins for their houses (Inden 1998, 50). Held to contain substances of both entities in their own bodies, Hindu kings in India claimed the capacity to regulate the days, months, and years as a result of being empowered by the Sun and Moon to act and to govern the world. Similarly, inscriptions made on behalf of medieval Sinhala kings often asserted their connection to the Okkāka dynasty, deriving from the mythical King Okkāka, from whom most of the kings of early India traced their descent in the Purānic genealogies (Perera 2003, 2:47). Associated with the Sun and with the same Sākya lineage as Gautama Buddha, medieval Sinhala kings were inclined to claim this same lineage of the "Solar Dynasty" for themselves.

The growth in Sinhala inscriptions written in the praśasti style to celebrate the king and to enhance his capacity to act in the world occurs between roughly the ninth and thirteenth centuries in Sri Lanka. Stylistically, these resemble descriptions of sovereignty in Cōla and Pallava inscriptional praise, which suggests that kingship was conceived in similar ways, albeit with Buddhist and Hindu variants, across South Asia at this time. Although the Sinhala praśastis reflect diverse styles and subjects, these inscriptions contain some notable similarities. They typically contain statements that praise a king for his genealogy, his physical appearance, his moral qualities, and his noteworthy deeds. For instance, the Jētavanārāma slab inscription from the eleventh century contains clear examples of such eulogistic praise for a Sri Lankan king. Mahinda IV is said to have been a descendent from the royal Okkāka dynasty, which abounds in a multitude of virtues, and causes other kșatriya dynasties to render homage (Wickremasinghe 1912, 1:224). His glory is said to illumine the entire island of Lankā, while his gentleness compares to the moon, his profundity to the ocean, his firmness to Mount Mēru, and his wealth to Kubera, the God of Wealth, among the other ten kingly virtues he is said to possess (Wickremasinghe 1912, 1:225). The inscription goes on to list many of the meritorious deeds performed by the king, including all the various monasteries and relic shrines that he repairs. This praśasti inscription depicts King Mahinda IV in superlative terms, con- 
firming that he was anointed with the abhiseka ritual, crowned, and bestowed with "world supremacy," a status that brings him wonderful presents offered by the kings of various other lands who submit to his authority (Wickremasinghe 1912, 1:225). Glory, wealth, and power are just some of the most common virtues attributed to a Sri Lankan king in inscriptions from the period.

Even more impressive praise is inscribed and attributed to King Nišśankamalla, who reigned from 1187-1196. In the extensive Galpota ("Stone Book") inscription at Polonnaruwa in the northeast of the island, this king is celebrated in great detail for his genealogy and his many wondrous virtues. Said to have been born in Dambadiva like the Buddhas, Bodhisattvas, and Universal Monarchs before him, Niśśankamalla is portrayed as the (attractive and distinctive) forehead mark (tilaka) of the Okkāka Dynasty, and this inscription confirms his right to rule in Lankā by his lineal succession and by virtue of having received sacred unction and the crown (Wickremasinghe 1928, 2:115). This king was the recipient of extensive praise in numerous inscriptions. Not only was he said to have been the equal of Śakra, the Lord of the Gods, in terms of his regal splendor, but he is also said to have performed miraculous events based on the power of his majesty. These include his alleged ability to disperse clouds at his coronation by frowning at them, his act of growling at a hostile bear and killing it in this manner, and an ability to command a viper to bite itself rather than him (Wickremasinghe 1928, 2:116). His power as king is further, and more conventionally, displayed by the accounts of his generous gifts made to others and his receipt of princesses and tributes from other countries. There is little doubt that the inscription serves to distinguish the king as an extraordinary being deserving of the command that he wields.

But perhaps the most significant feature in the Galpota inscription is the statement, "Though kings appear in human form, they are human divinities [nara-devatā] and must, therefore, be regarded as gods [deviyan-sē däkka-yutuyä]" (Wickremasinghe 1928, 2:113, 121). This statement draws a clear parallel between Sri Lankan kings and living deities, and the former are implicitly said to be particularly deserving of honor. This inscription is often cited by scholars in order to advance the thesis that Sri Lankan kings were once viewed and treated as living gods. The language of the text, and the wider context of expressive praise in which it is found, appear to suggest that the author sought to show that kings should be looked upon like gods. This phrase, however, does not seem to indicate the literal identification of kings as actual gods. This king's great power and majesty, bordering on the divine, are understood to be functions of the merit earned during his previous lives. ${ }^{2}$ Analogous to gods who are understood to reap the heavenly benefits of merit performed in previous lives, kings also enjoy the fruits of their exceptional good deeds done earlier.

The inscriptional evidence of extensive praise being offered to kings casts Sri Lanka's Buddhist monarchs in a different light than what one usually finds in most vamsa texts. The kings appear in Sinhala inscriptions not only as generous supporters of the Sangha, but as powerful, godlike beings whose wealth of merit and material objects is reflected in their extraordinary splendor and fame. In this way, Sinhala praśastis appear to imitate inscriptional practices found in South India at this time, wherein one finds recounted the deeds of valor of the king, his powers in battle, his wisdom in administration, his personal qualities, his works of charity, and his royal lineage (Perera 2003, 2:44). Rather than just emphasizing their righteous adherence to the Buddha's Dhamma, Sri Lankan kings in the medieval period were described

2 Another view holds that what links kings and gods (and bodhisattvas) is the parallel nature of their duties to protect and propound the Dharma. See Holt (1991), p. 61. 
in more heroic and martial terms, and they were given epithets used in South India to denote military prowess and valor (Pathmanathan 1982, 140-42). The inscriptions also begin to attribute divine qualities to kings in Sri Lanka in the midst of praising them for what are often described as "a multitude of boundless and illustrious qualities" (Perera 2003, 2:51). In other words, kings in praśastis are said to excel in all things. And it seems likely that their allegedly superhuman qualities are what led Sinhala authors to compare them with gods.

A fine example of a Sinhala king's divine qualities is seen in the twelfth-century Devanagala rock inscription of King Parākramabāhu I (r. 1153-1186). In this praśasti, the king's wondrous characteristics are depicted with reference to a host of Indic gods that serve to illustrate his greatness. In each case, Parākramabāhu excels the divine exemplar of a particular virtue, clearly establishing the king as unparalleled in every way. The king is described in the inscription as one "who surpasses the Sun in his glory, Maheśvara in prowess, Viṣnu in pride, Indra in kingly deportment, Kuvera in abundant wealth, Kitisiru in happiness to beings, Bṛhaspati in the excellence of his wisdom, the Moon in gentleness, Kâmadeva in the excellence of his beauty, and the Bodhisattva in the fullness of his benevolence" (Paranavitana 1933, 3:323-34). This inscription indicates something about the greatness of this king by comparing him favorably to the gods who would normally be seen as paradigmatic for each of these individual qualities. This is high praise indeed. The use of Indic gods to lavish praise on Sri Lankan Buddhist kings illustrates how these deities could function metaphorically in inscriptions to enhance the fame and standing of living rulers. When seeking to show how a king possesses an abundance of personal virtues, the artful comparisons to gods served to place him above all others. In this way, the diffusion of Hindu theologies of kingship into Sri Lankan culture could lend greater stability to the institution of kingship on the island, enhancing the stature of local kings by making them comparable to noteworthy kings in other lands. Eulogistic praise in inscriptional writing served to express the idea of a king's command, glorifying his character and universalizing his claims to power in a competitive field of South Asian imperial expansion (Graeber and Sahlins 2017, 13).

\section{Poetic Praise of Buddhist Kings}

As the images of Sri Lankan kings became more elaborate and impressive due to the dynamic use of Indian styles of inscriptional praśasti writing, the portrait of kingship was further refined in poetic works composed in the Sinhala language between the twelfth and sixteenth centuries. The rise in the composition of Sinhala poetic works coincided with the vernacularization of Sinhala literature in the second millennium of the Common Era. As Pollock has argued, regional literary cultures such as Sinhala gradually came to adopt the rich poetic style and literary norms of Sanskrit kāvya (Pollock 2004, 254). The resultant Sinhala poetry sought to emulate the claims to universality and literary excellence of Sanskrit poetry, while retaining the use of the local literary language to express its sentiments and ideas. The first kings described in Sinhala poetry were usually stories about the Bodhisattva in his previous lives when he served as a king or in some other role while on his path to eventual Buddhahood. But by around the fourteenth century, one begins to find compositions of Sinhala poetry that celebrate living kings who reign over their kingdoms in the island. These poetic works, which themselves were influenced by Sanskrit literary culture and the Hindu ideals that often grounded its expressions, contributed further to the divine representations of Buddhist kings in Sri Lanka (Berkwitz 2013, 12-15). 
Buddhist kings become important topics for praise and reflection in texts such as the Sinhala sandēśa poetry composed by monks and laypersons. These particular works imitated a wider, pan-Indic genre of messenger poetry in which one party sends another party a message that is carried by a bird, a bee, or some sort of natural phenomenon, such as a cloud. Following the sixth-century Kālidāsa's renowned Meghadhūta (Cloud Messenger), authors from all over South Asia sought to demonstrate their own devotion and poetic skill by composing a poem in the form of a stylized message. Sinhala poets were included in this effort, although they distinguished their own literary works by transforming a genre of poetry about pining lovers into a tool for representing and celebrating kingship (Berkwitz 2017, 96). Indeed, most messenger poetry composed on the subcontinent emphasized separated lovers who longed to be reunited. Sinhala authors, on the other hand, used these poems to construct powerful and majestic portraits of kings, and to enlist birds to send messages to local deities to bless the ruler and his family. Sinhala sandēśa poetry typically praised contemporary Buddhist kings for their virtues of fame, strength, beauty, wisdom, wealth, and devotion to the Three Jewels, among other qualities. Like in the inscriptions that appeared earlier, poetic works from this period depict kings as extraordinary beings who have more in common with gods than with ordinary people.

We see examples of poetic eulogies of Buddhist kingship in a number of different Sinhala sandéśas from this period. The fourteenth-century Mayura Sandēśaya (Message of the Peacock) describes King Bhuvanēkabāhu V (r. 1372-1408) as "being another Śakra in terms of having immeasurable wealth" (Liyanarachchi 2007, v. 16). This line describes how the opulent majesty of the king calls to mind the divine Lord of the Gods, who likewise possesses great riches. Another fourteenth-century text, Tisara Sandéśaya (Message of the Swan) compares King Parākramabāhu V (r. 1344-1359) to the god Bṛhaspati when it asserts that he is "renowned in the world like the Teacher of the Gods in knowing all of the treatises of learning" (Gunasekara 1986, v. 158). Not only supremely wealthy and generous, Sinhala kings ought to be well-read and knowledgeable, too. Yet another example of a godlike king comes from the mid-sixteenth century Sävul Sandéśaya (Message of the Cock). This poetic work contains numerous verses offering rich, expressive praise to King Rājasinghe I (r. 1581-1593) in a manner resembling praśasti writing. It repeatedly compares the king to Śakra in terms of his splendor and majesty, and to the god Viṣnu in terms of his strength and skill in battle. One verse in particular serves to illustrate how the poet ascribes divine qualities to the king:

Because of the great and pure heap of fame of this Lord of Men,

When he has the shining body of Viṣnu and the appearance of Iśvara,

He dwells happily, dispelling the doubt

From the faultless, long, wide, and brilliant eyes of Śrī

(Tennekoon 1955, v. 51).

The poet who composed this work, a layman named Alagiyavanna, employs divine imagery to praise the physical appearance of King Rājasinghe I, associating him with powerful Hindu gods to such an extent that even the goddess Śrī is said to be unable to distinguish the king from her divine husband. For Sinhala poets, gods offered attractive metaphors for enhancing the power and reputations of their royal patrons.

We find even more examples of how a Sinhala king is compared to gods in the fifteenthcentury Pärakumbā Sirita (Account of King Parākramabāhu VI). This poetic work reads like an extensive praśasti in verse form to celebrate one of the great medieval Buddhist kings from Sri 
Lanka. The anonymous courtier who composed this work of 140 verses frequently employs divine imagery to describe his king in superlative terms. He, too, compares the king with Śakra in wealth, Bṛhaspati in knowledge, and Viṣnu in might, utilizing familiar divine tropes to praise the king's many outstanding qualities (Berkwitz 2016, 336). But this work goes even further in attributing the king with extraordinary characteristics. His physical beauty is evoked by describing him as "an incarnation of the God of Love" and as having a "beautiful appearance like that of Kuvera, the God of Wealth" (Abhayagunaratana [1929] 1997, vv. 108, 124). He is compared to Rāma for his strong arms and prosperity (Abhayagunaratana [1929] 1997, vv. 108, 124). And he is called a "Buddha-aspirant" (budukuru), or a bodhisattva, due to his splendid appearance from wearing a golden crown (Abhayagunaratana [1929] 1997, v. 40). In fact, the cumulative effect of the many divine metaphors used to describe Parākramabāhu VI eventually wearies the poet, and he begins to affirm that the king's qualities exceed even those of the gods themselves. Thus, the king of Sri Lanka is said to surpass Sakra, the King of the Gods, as he is the lord of the four directions and has an army of elephants, while the latter is only the lord of the east and possesses only one tusker (Abhayagunaratana [1929] 1997, 114). We are told, furthermore, that even the divine Brahmā and Ananta are unable to list and recite all of the boundless virtues of this king (Abhayagunaratana [1929] 1997, 96).

Sinhala poets, with their expressive uses of figurative language, developed and promoted notions of divine kingship that were borrowed from the subcontinent and modified for use in the Sri Lankan context. Picking up on the cultural work of eulogistic inscriptions, medieval Sinhala poetry made kings into the subjects of ornate, well-constructed praise. Given that the most common setting for poetic composition and recitation at this time was the royal court, we need not be surprised by the fact that Buddhist poets were often in the business of celebrating kings. Nevertheless, the metaphorical use of gods in verses for praising kings is noteworthy. Like the scribes who incised words of praise into rock and metal plates based on models of praśasti writing elsewhere in India, Sinhala poets emulated Indic poets who likewise depicted kings as extraordinary, godlike beings. They compared their royal patrons to gods, or even claimed that they surpassed them in terms of their qualities. Sri Lankan kings and their bards inhabited a politico-cultural system where the aesthetic use of figurative language was central to the creation of a king's reputation. Poets regularly praised kings for being like gods, the moon, mountains, lotuses, and other suggestive images.

Yet if there is a difference between these Sinhala texts and the Hindu treatises that make assertions about the divinity of kingship, it is that the Sinhala texts express the divinity of kings in mostly metaphorical terms, stressing that Sinhala kings are like certain gods, without clearly claiming that they are in fact divine. Sinhala Buddhist kings remained functionally similar to gods, as demonstrated also by earlier Indian authors, but there is scant evidence to suggest that these descriptions were consistently interpreted as anything more than poetic devices. ${ }^{3}$ The relations made between Sri Lankan Buddhist kings and gods are, in most cases, constructed along the conceptual connection "as if" rather than "is," or alternatively in terms of metaphors rather than one-to-one identity (Kövecses 2015, 44). Some scholars might argue that kings and gods were viewed along the same continuum, for example in Inden's "Hindu Chain of Being," in which the entire cosmos is seen as a hierarchical chain of relational essences that are constituted in an overlapping series of lordships (Inden 1985b, 56-57). In such a framework,

3 Here I depart from the arguments of S. Pathmanathan, who maintains that epithets for Hindu kings such as "rājanārāyana" were borrowed by Sinhala rulers and meant that they were actually seen as avatars of Viṣnu (Pathmanathan 1982, 138-39). Beyond such claims in eulogistic writing, I find little evidence to sustain the claim that such expressions were not metaphorical during the medieval era. 
kings are both functionally and materially connected with the gods who rule over the universe. However, as Inden himself has noted, Buddhist cosmologies often functioned quite differently than Hindu ones, which meant that kings in predominantly Buddhist cultures could not easily be seen as the incarnations of deities on earth (Inden 1985a, 160-61). In the medieval period, broadly speaking, of Sri Lankan history, the moves to conflate kings and gods consistently appeared in panegyric writing, where aesthetic language and figures of speech were central to the expression of royalty. References to gods helped to enhance the reputations and public standing of kings, but such an elevation of status continued to operate at the level of figurative rather than literal speech.

\section{On Bodhisattva Kings}

An extension of the trope of the godlike king in Sri Lanka was the development of the idea that kings were bodhisattvas or Future Buddhas. Praising a king for being a "Buddha-aspirant" (budukuru) became a useful way to highlight royal virtues such as generosity and a dazzling regal appearance. And as we will see, drawing on bodhisattva imagery also reinserted Buddhist ideas to the array of divine metaphors borrowed from Hindu sources, stabilizing local traditions that were being revised by the dynamics of the discourse of divine kingship. To this end, a famous eleventh-century inscription from Sri Lanka asserts that "none but bodhisattas would become kings of Sri Lanka" (Wickremasinghe 1912, 1:240). Based largely on this statement, Sri Lankan and Western scholars alike have suggested that the medieval era in Sri Lanka was marked by the perception that the kings of the island were all "bodhisattva kings." It would be wise, however, to refrain from interpreting such eulogistic statements as literal, widespread statements of belief. Instead, most of the references to bodhisattva kings seem to have been chiefly metaphorical in nature, reflecting attempts to draw upon the most praiseworthy lay Buddhist figure to enhance and universalize the reputation of kings in Buddhist communities. Comparing a king to the figure of the bodhisattva provided authors with another way to eulogize living rulers, in a manner much like the use of divine imagery in inscriptions and texts. Their juxtaposition in written works glorified kings and compelled their subjects to pay them the utmost respect and loyalty.

Indeed, most of these inscriptions on the bodhisattva king, which are fairly small in number, liken a particular king to a bodhisattva in terms of certain virtues he is said to possess. For instance, King Niśśankamalla (1187-1196) is said to be attached to the virtuous qualities of a bodhisattva king who, "like a parent, protects the world and the religion" (Wickremasinghe 1928, 2:176). Elsewhere, King Vijayabāhu I (1040-1114) is said to have surpassed not only the gods in his prowess, wealth, and wisdom, but also the bodhisattvas in the "fullness of his benevolence" (Wickremasinghe 1928, 2:215-16). This inscription describes the king as being resplendent in his crown and royal dress as he pours out measureless treasures to needy people. He therefore resembles a bodhisattva both in appearance and in deed. In another inscription, Mahinda IV is said to have determination like that of a bodhisattva to repair a monastic building (Wickremasinghe 1912, 1:227-28). In these few statements, the kings' associations with a bodhisattva seems to be chiefly metaphorical and made for literary effect. It is consistent with the panegyrical style of praśasti writing to employ the image of a bodhisattva to describe the exceptional compassion, generosity, and resolve of a Buddhist king. Comparisons to a bodhisattva offered authors an alluring image to celebrate the virtues of a 
king with a recognizably Buddhist figure that embodies the most highly refined good qualities imaginable, short of a Buddha himself.

These comparisons to a bodhisattva serve to enhance the fame and prestige of a living king in much the same way that comparisons to gods could generate fame and admiration. The fact that, more often than not, kings are compared to both gods and bodhisattvas in the same inscriptions and poetic verses suggests that these poetic images likewise functioned metaphorically to describe a king's superior qualities in universalizable terms. This interpretation is consistent with what Lakoff and Johnson have argued regarding the human tendency to conceptualize nonphysical, less clearly delineated things in terms of physical, more clearly delineated things through the use of metaphors that give abstract ideas more tangible, understandable forms (Lakoff and Johnson 1980, 59). In other words, whereas many scholars have read a single inscription to mean that kings in medieval Sri Lanka were widely seen as actual bodhisattvas, I argue that comparisons drawn between kings, on the one hand, and gods and bodhisattvas, on the other, formed elaborate, poetic techniques to eulogize rulers and enhance their power and authority on the island and beyond.

Sinhala Buddhist poets picked up on the bodhisattva metaphor in their works, too. Such descriptive praise becomes a recurring feature in several fifteenth-century works that were composed to eulogize King Parākramabāhu VI. Not only is this king said to be like the gods in his personal qualities, he is also like a bodhisattva and therefore worthy of praise and admiration. By embodying the manner and appearance of a bodhisattva, the king surpasses even the gods to whom he is otherwise compared. The fifteenth-century Sinhala mahāka $\bar{v} v a$ called Kāryaśēkhara (Crown of Poetry) describes this king as possessing "the delightful splendor of a bodhisattva" while knowing the entire Dharma and protecting the purity of the world and the Buddha's dispensation (Dharmarama 1966, v. 8). The poet Śrī Rāhula describes the king in this verse as resembling a bodhisattva in terms of the light he manifests from his body. This resemblance, moreover, stops short of enjoining readers and listeners of the work to view or worship the king as a literal bodhisattva. Instead, what we see is one example among several others where the description of certain Sri Lankan kings as being like a bodhisattva functions as a form of rhetorical auxesis, or a conspicuous means for amplifying and exaggerating the virtues of the king (Berkwitz 2016, 334).

One of the more compelling verses comparing King Parākramabāhu VI to a bodhisattva appears in the fifteenth-century Kōkilasandéśaya (Message of the Cuckoo). Although this fleeting comparison is overshadowed by other metaphors in the work, it nevertheless signals some of the royal attributes that could be illustrated poetically through the artful use of the image of a bodhisattva, or one aspiring to Buddhahood.

This Lord of Men, who is a Buddha-aspirant, filling his ears,

With the flavor of the meaning of the Tripitaka Dharma, preached by the

Omniscient One,

While continually increasing his virtue, delighted the bees of alms-recipients,

With the pollen of the six-colored gems and the red water-lilies of gifts

(Perera [1906] 2009, v. 139).

Here, the poet associates the king with a bodhisattva due to his alleged adherence to the Dharma and his munificence in giving alms. The king is lauded for his piety and generosity, expressed in his wish to become a Buddha in the future. By identifying Parākramabāhu with a bodhisattva, this text confers upon the king some of the highest virtues imaginable for a 
Buddhist ruler. Only a fully awakened Buddha could be deemed higher than a bodhisattva, but Buddhas by definition renounce the household life to live as an ascetic. As long as a king remains on the throne, the most noble paradigm he could embody is that of a future Buddha, or a bodhisattva who could still live as a layperson. Such a metaphor drawn from the Buddhist tradition lends stability to the notion of Buddhist kingship as that which is akin to but also distinctive from Hindu models of extraordinary beings.

It should also be noted that comparisons of kings to bodhisattvas almost invariably include comparisons to gods, which demonstrates that bodhisattva kingship can be seen as an extension of divine kingship in Sri Lanka, albeit a metaphor that is more distinctive to the Buddhist cultural context in the island. Adding the bodhisattva to the domain of metaphors to describe kings reflected the creation of a new poetic image from the immediate cultural setting in Sri Lanka, and one that was a salient image for Buddhist audiences. It illustrates how the immediate cultural and social setting, as well as previous discourse about kings in Sinhala texts, could make the metaphor of the bodhisattva king a fairly common feature (Kövecses 2015,130 ). One could even argue that a comparison to a bodhisattva was even grander than one made to a god, since in the traditional Buddhist cosmology a bodhisattva was considered morally superior and more spiritually advanced than the deities. Yet bards and poets were not forced to choose between them, as they frequently associated their kings with both types of extraordinary figures. Nevertheless, the introduction of the bodhisattva king to the eulogistic discourse on Buddhist kingship allowed authors to indigenize the rhetorical flourishes of divine kings borrowed from neighbouring Hindu contexts and influences. Praiseworthy descriptions of kings across South Asia at this time utilized superlative imagery that illustrated the permeable borders between what nominally could be called Buddhist and Hindu models of kingship. In fact, it would be more accurate to refer to various articulations of South Asian kingship in Buddhist and Hindu contexts.

\section{From Godlike to Divine Kings?}

When medieval Sri Lankan kings were described in panegyrical texts as being like gods and bodhisattvas, they were being honored for possessing virtues that surpassed those of ordinary humans. Poets and bards that celebrated living kings adopted much of the manners of praising kings from Indic praśasti and kāvya writing. Royal eulogy thus became a popular site for interreligious and intercultural exchanges between traditions in medieval South Asia. Hindu portrayals of divine kingship in inscriptions and texts became influential as Indic literature and Hindu kings assumed a greater presence and influence in Sri Lanka following increased trade and the invasion and occupation of parts of the island in the eleventh and thirteenth centuries. Brahmin functionaries performed numerous rites for kings, including the abhiseka consecration to invest the king with his royal powers and identity (Nicholas and Paranavitana 1961, 248). Meanwhile, medieval Sri Lankan kings formed alliances with certain Indian kingdoms, and engaged in exchanges of envoys, gifts, and marriages with friendly Hindu kings, while also routinely welcoming scholars from India into the island (Nicholas and Paranavitana 1961, 194-97). The contacts with the Cōla, Pāṇ̣ya, and Kalinga kingdoms in India reshaped Sinhala kingship in Sri Lanka, introducing more "Hindu" influences on the king and court (Pathmanathan 1982, 122). These contacts introduced new dynamics into local, Buddhist traditions of kingship, texts, and practice. Sinhala kings who were ordinarily expected to affiliate with the Buddha, the Dharma, and the Sangha began to become conceived and 
praised in different ways, ways that often resembled the depictions of divine Hindu kings in medieval India. Sri Lankan Buddhist authors embraced metaphors of divine beings to enhance the fame and power of their own kings, so as not to be diminished by the praise afforded to their rivals in India. Sinhala eulogistic writing reflected political technologies of royal aggrandizement in manners that crossed over both religious and sectarian boundaries, entangling their notions of divine kingship.

The mingling of cultures and traditions in medieval Sri Lanka may also have laid the groundwork for a more radical reconceptualization of kingship in subsequent centuries. Metaphors of kings may not always remain figurative and suggestive in nature, but they may also claim the power to create new realities amidst shifting interpretations in a given culture (Kövecses 2015, 83). In the case of Sri Lankan Buddhist kingship, this means that in later centuries metaphorical attributes could sometimes become taken as genuine facts and literal statements. The continual references to Buddhist kings as being like Indra, the king of the gods, could eventually turn them from being merely "godlike" to actually being divine. There are scattered hints that seem to suggest that from time to time, Sri Lankan Buddhists began to view their kings as actual gods and bodhisattvas in later centuries. For example, a fifteenth-century inscription describes King Parākramabāhu VI (1412-67) as an "incarnate Bodhisattva" (bodhisatvāvatāra) due to his great merit and boundless authority, while expressing the confident expectation that he will one day become a Buddha (Paranavitana 1933, 3:66-68). This same king is described in the poetic work Pärakumbā Sirita as having been born as a "Buddha aspirant," which suggests that his identification with a future Buddha may sometimes be more integral than just an expression made for literary effect (Abhayagunaratana [1929] 1997, v. 27). It seems reasonable to conclude that the authors and bards who felt compelled to praise their king would eventually look for more extravagant ways of doing so. The association between Buddhist kings and bodhisattvas was sufficiently strong by the fifteenth century so as to allow for the logical extension of metaphorical praise to result in stronger claims for the real identity of a bodhisattva king. Still, the less figurative use of bodhisattva imagery does not mean that all Sinhala kings were taken to be aspiring Buddhas. Indeed, the literary contexts for such claims were eulogistic and served the purpose of glorifying the living ruler. The potential for a diversity of views on the king's person in Sri Lanka cannot be dismissed.

There are signs, moreover, that the metaphorical divine king in Sri Lankan culture may also have been taken in more literal terms as time passed. In the later Kandyan Period of Sri Lankan history, which occurred from roughly the eighteenth century to the early twentieth century, there are indications that the metaphors of divine and bodhisattva kings were sometimes understood as genuine descriptions of contemporary rulers. The Kandyan king was addressed as "god" (deva), regal symbols of sun-shades and whisk fans were associated with both kings and gods, and the ritual abhiseka coronation had the specific function of transforming the king from a man into a god in the view of his subjects (Seneviratne 1978, 2). Thus, what began as a metaphor may have eventually and occasionally been interpreted as the description of an actual divine king whose powers exceed those of ordinary persons. To be clear, the extent to which literal interpretations of divine kings can be found in premodern Sri Lanka remains debatable. However, the further removed Sri Lankan Buddhists were from the elite literary cultures of Sanskrit and Sinhala poetics, the more difficult it could have become for people to distinguish metaphorical usages from empirical statements of fact. This is not to say that all Sinhala Buddhists understood their kings to be divine by nature. But the proliferation of metaphors concerning the king's divine and royal qualities may have eventually laid the 
groundwork for interpreting Sri Lankan kingship in terms of divine or at least quasi-divine rulers. More research into the later discourse on kingship is needed to make these assertions with any certainty.

The argument here is admittedly a nuanced one. Yet it seems reasonable to contend that metaphors of divine kingship, including the related metaphor of bodhisattva kingship, could at times be interpreted more literally. The fact that there is some evidence for this starting around the fifteenth century should not be taken to mean that kings were always really seen to be gods or bodhisattvas after the fifteenth century. There is some evidence, however, to suggest that the conventional metaphors of divine kingship were at least occasionally interpreted as describing genuine divine kings in Sri Lanka. The popularity of conventional descriptions of kings as gods and bodhisattvas may well have reinforced a trend toward more literal interpretations of royal divinity during the latter part of the second millennium CE. At the same time, it is unlikely that older, metaphorical interpretations were suddenly cast aside for literal ones. One imagines instead that literal interpretations of divine and bodhisattva kings were more the exception than the norm in Sri Lanka. Phrased differently, references to divine kingship, especially in the context of panegyrical genres, appear to have been variations on a common trope for bestowing greatness to important figures. The Theravāda Buddhist cosmology tended to make clear-cut distinctions between gods and humans, and the transformation of one into the other would generally happen only on the occasion of rebirth and would entail inhabiting a wholly different sphere of existence. Our limitations in obtaining insights into what premodern Buddhists really thought about their kings make it necessary to consider both possibilities-on the one hand, that the metaphors remained largely metaphorical for Sri Lankan Buddhists, and on the other hand, that metaphors could remake the reality they purport to describe.

\section{Dynamics and Stability in South Asian Kingship}

This account of "divine kingship" in Sri Lankan Buddhism provides us with a case study of how interreligious and intrareligious contacts served to transform the notions publicly associated with a Buddhist king. The incorporation of divine imagery, including the related notion of the bodhisattva king, suggests that Sri Lanka's Buddhist traditions took an inclusive approach to representing royal power and identity. Literary borrowings from Indic praśasti and kāvya works enabled Sinhala authors to pattern their praise of local kings after the eulogistic writings from the mainland. These dynamics led these authors to build upon traditional Buddhist conceptions of "righteous kings" (dhammaräja) and "universal monarchs" (cakkavattin), and to add in extraordinary qualities of kings that could be conveyed by metaphorical allusions to gods and bodhisattvas. These transformations in the ideals of kingship in medieval Sri Lanka underline the view that there was no single "Theravāda" theory of kingship, but rather a rich array of images and metaphors that were used to construct power and sovereignty in different historical circumstances.

Conceptions of kingship were influenced by Buddhist thought in Sri Lanka but were not entirely determined by it. The strands of an ostensibly "Buddhist" kingship that were developed and presented within the vamsas helped to shape how many Sri Lankans perceived their kings as righteous rulers devoted to the maintenance of the world and the promotion of the Buddhist religion. Yet the dynamic incorporation of external ideas about divine kings and celestial bodhisattvas in Sinhala and Pāli texts gave rise to new notions that expanded people's 
understandings of the nature of kings. As a result of these interreligious and intrareligious contacts, Sri Lankan Buddhists began to speak of their kings in more grandiose terms. They celebrated not only the kings' notable deeds on behalf of their subjects and the Buddha's sāsana, but they also increasingly made a point of honoring the kings' extraordinary personal attributes and virtues (Berkwitz 2016, 332). Describing their kings in terms resembling gods such as Śakra and Viṣnu, medieval Sri Lankan Buddhists transformed what it meant to be a king along pan-Indic lines. Shaped by contacts with Hindu texts and brahmanical rituals, Buddhist kingship in Sri Lanka was infused with new dimensions and performances that were nonetheless modified to fit local Buddhist values and practices.

One of the key questions underlining this study is why Sri Lankan Buddhists incorporated numerous, otherwise "Hindu" notions of kingship to such a vigorous extent. Some have argued that the conflation of royalty and divinity in South Asia was primarily a strategy to invoke a religious symbolism in an attempt to legitimize the king's political power (Veluthat 2009, 38). The thinking here is that the identification of the king with a deity would naturally inspire more esteem and veneration from his subjects. Ideas of "divine kingship" have been recurrent features in the scholarship on power in premodern South Asia. At times, this notion has served as little more than a trope used to dismiss the validity of kingship and the allegedly false consciousness that it generates in ordinary devotees. Meanwhile, other scholars have associated divine kingship with an ancient and essential feature of governance in South Asia, arguing that it was a necessary aspect for the maintenance of authority in premodern India (Inden 1990, 165). The controversy surrounding this notion has much to do with the way it has been deployed by colonial critics of indigenous governments and the alleged "Oriental despotism" it supported. The assumption that medieval kings in South Asia required legitimation in the first place is itself a problematic one. As noted by Pollock, there is no basis for doubting the inevitability of kingship in medieval South Asia, or for thinking that kings required the formal assent of their subjects in order to rule (Pollock 2006, 522). It is certainly possible that the panegyrical comparisons of kings to deities helped to bolster the reigns of the former and the reputations of monarchs in the eyes of the public. Yet to conclude that this was the primary function of eulogistic praise for kings is to make the questionable assumption that the chief role of kings and their bards was to convince the public of their right to rule, as if this idea was always somehow suspect and contentious.

Instead, the entangled theologies of kingship in medieval Sri Lanka point more to attempts to enhance the fame and power of particular kings to strengthen the image of their reigns both at home and abroad. Borrowing various Hindu models of divine kingship, which themselves could have at times been chiefly metaphorical in nature, Sri Lankan authors employed inscriptions and poetry to portray their kings as divine in function and appearance. These literary displays of the ruler's power, accompanied by the building of grand monuments in his kingdom, expressed a great deal about the king's power and resources to govern (Veluthat 2009, 44). The absence of such praise and building programs would not have necessarily caused his subjects to question the legitimacy of his rule. But the public celebration of the king's qualities appears directed toward inspiring more respect and loyalty at home, and to give rise to more deference and fear among those in other kingdoms. Depictions of kings in godlike terms were ways to universalize their claims to power and authority, in much the same way that the Indic gods to whom they were regularly compared could claim to wield the power of command over distant lands. It would appear, then, that Sri Lankan kings were not identifiable with gods per se, but rather empowered to act like them in forceful and even arbitrary ways (Graeber and 
Sahlins 2017, 81). While ruling on the periphery of the subcontinent, Sinhala kings claimed to be the politico-cultural equals of great Indic kings, their matches in power and glory. To be described in terms of gods helped to make Sinhala kings competitive with other monarchs across Southern Asia, comparable to gods and eager participants in the conquest of the four quarters of earth (digvijaya). Such conquests typically involved, in theory, the defeat of one's enemies, the conquest of territory, and the establishment of the rule of Dharma (Sax 2000, 52). While most Sri Lankan kings adjusted their aims to conquering the entirety of the island, the refined comparisons to divine beings would have likely made it seem that such royal objectives were entirely possible. Thus, in medieval Sri Lanka, the idea of "divine kingship" was mainly a literary trope to enhance and universalize a king's reign in terms that were familiar across sectarian lines in premodern South Asia.

Advances in the scholarship on Buddhist kingship require taking a more dynamic view of the offices and practices associated with kings in Buddhist cultures. To approach the subject in terms of the ideals connected with King Aśoka's reign in ancient India is to take an overly limited and static view of what Buddhist kingship entailed over the centuries (Ahir 2011). Indeed, while some kings expressly emulated Aśoka, others modeled their reigns after other figures, both human and divine. In Sri Lanka, between the tenth and sixteenth centuries of the Common Era, kingship was the intellectual product of various strands in the representation of power and sovereignty in Southern Asia. Encounters with varieties of rituals, literature, and iconography from Indic cultures spurred new developments in how Sri Lankan Buddhists imagined and portrayed their kings. The expansion of ideas of kingship did not, however, undermine longstanding local traditions. Instead, one sees efforts made to stabilize Sinhala religious traditions by rendering divine kingship into a metaphorical notion that could exalt a living ruler without violating accepted ideas about the humanity of kings who ruled on earth. The use of Indic gods to elaborate upon the king's virtues was further tempered by adding in comparisons to Buddhist bodhisattvas. This limited the reliance on external sources for imagining kingship, and helped to stabilize and differentiate a specifically "Buddhist" type of kingship that could rival those in Hindu cultures while retaining a distinct identity.

When evaluating the development of kingship in medieval Sri Lanka, we see practical efforts to incorporate elements of divine kingship from Hindu kings and their subjects. The dynamic adaptation of these features proceeded largely along the lines of rendering such notions into metaphors for the sake of praising the ruler. It does not seem likely that such descriptions of kings being like gods were taken literally, at least not until later centuries, when there was more distance between the original Sanskrit aesthetics of court poetry and audiences in later centuries who were less well-trained as connoisseurs of literature. The efforts to introduce new dynamics into kingship were offset by other initiatives undertaken to reassert stability and continuity in local Theravāda Buddhist traditions. In this way, so-called "divine" Buddhist kings appeared to be divine chiefly in eulogistic writings meant first and foremost for the king and his court. Suggestions that such kings appeared as if they were divine maintained a measure of distance from corresponding Hindu notions that could embrace human kings as divine incarnations (avatāras) more readily. Another measure to stabilize Buddhist conceptions of kingship was to utilize the figure of the bodhisattva as another metaphorical device to celebrate living rulers. Although this image of the glorious and crowned bodhisattva seems to have been borrowed from surviving elements of Mahāyāna Buddhism in the island, the bodhisattva notion was still easily identified as a Buddhist figure.

We may now assert with confidence that Buddhist kings in medieval Sri Lanka were de- 
picted and imagined in more diverse and complex ways than scholars have often recognized. Contact with interreligious and intrareligious communities spurred dynamic developments in the office of kingship, while also spurring corresponding efforts to stabilize and sustain local religious and cultural traditions by rendering divine imagery as primarily metaphorical and invoking the image of the bodhisattva to complement those linked with Hindu gods. Written expressions of divine kingship and bodhisattva kingship in medieval Sri Lanka were thus not always straightforward affairs that display to us the actual beliefs of premodern Buddhists. Different strands of kingship in Sri Lanka created complexities and occasional ambiguities in the representation of royal power. What is abundantly clear, however, is that kingship in medieval Sri Lanka was greatly expanded by the dynamics of cultural interactions and exchanges, creating new images of power and sovereignty to enhance the image of the Sri Lankan king within the larger pan-Indic context in which it operated. Notions of divine kingship and bodhisattva kingship were incorporated and adapted to fit local religious and cultural circumstances. These adaptations contributed to the stability of local expressions of Buddhist kingship by making Sri Lankan rulers comparable, if not superior to, other royal rivals and allies in terms of their fame, power, and virtue.

The ease with which Buddhist authors incorporated an array of images and literary tropes associated with kings across South Asia is indicative of the blurred identities and boundaries commonly seen in the premodern world. Viewing kingship as a product of religious and cultural entanglements helps us to see that although kingship may have had its various Buddhist and Hindu articulations in different times and places, it remained an interreligious domain for the construction of royal sovereignty and authority. Sri Lankan kings with Buddhist affiliations were made more powerful and attractive by depicting them in the broader terms of divine kings from Indic lore and literature. In remaking kingship in these universal ways, Sri Lankan Buddhists could celebrate their local rulers and simultaneously rest easy with the knowledge that the fate of the Buddha's dispensation had been placed in the strong, sure hands of a king who was like, among others, Aśoka, Viṣnu, and the Bodhisattva.

\section{References}

Abhayagunaratana, D. G., ed. (1929) 1997. Pärakumbā Sirita. Colombo: Madhyama Sanskṛtika Aramudala.

Ahir, D. C. 2011. The Great Buddhist Kings of Asia. Delhi: Buddhist World Press.

Ali, Daud. 2011. "Kingship." In Brill's Encyclopedia of Hinduism. Society, Religious Specialists, Religious Traditions, Philosophy, edited by Knut A. Jacobsen and Johannes Bronkhorst, 3:90-96. Handbook of Oriental Studies, Section 2 South Asia. Leiden: Brill.

Ariyapala, M. B. (1956) 1997. Society in Mediaeval Ceylon. Colombo: Department of Cultural Affairs.

Berkwitz, Stephen C. 2013. Buddhist Poetry and Colonialism: Alagiyavanna and the Portuguese in Sri Lanka. Oxford: Oxford University Press.

- 2016. "Reimagining Buddhist Kingship in a Sinhala Praśasti." Journal of the American Oriental Society 136 (2): 325-41.

— 2017. "Sinhala Sandēśa Poetry in a Cosmopolitan Context." In Sri Lanka at the Crossroads of History, edited by Zoltan Biedermann and Alan Strathern, 94-112. London: UCL Press. 
Blackburn, Anne. 2017. "Buddhist Technologies of Statecraft and Millennial Moments." History and Theory 56 (1): 71-79.

Deeg, Max. 2016. "The Order of the Dharma and the Order of Rulership: On the Relationship Between Monastic Community and Worldly Power in the History of Buddhism." In Frühmittelalterliche Studien, edited by Wolfram Drews and Christel Meier, 50:297-314. Berlin: De Gruyter.

Dharmarama, Ratmalane Dharmakirti Śri. 1966. Śrī Rāhula Māhimiyan Visin Viracita Kāvyaśēkhara Mahākā vya. Kelaniya: Vidyalankara University Press.

Francis, Emmanuel. 2013. Le Discours Royal Dans L'Inde Du Sud Ancienne: Inscriptions et Monuments Pallava (IVème-IXème Siècles). Vol. 1. Louvain-la-Neuve: Institut orientaliste de L'Université catholique de Louvain.

Geiger, Wilhelm. 1953a. Cülavamsa: Being the More Recent Part of the Mahāvamsa. Vol. 1. Colombo: The Ceylon Government Information Department.

- 1953b. Cūlavamsa: Being the More Recent Part of the Mahāvamsa. Vol. 2. Colombo: The Ceylon Government Information Department.

— trans. (1912) 2001. The Mahavamsa or, the Great Chronicle of Ceylon. Oxford: Pali Text Society.

Gonda, Jan. 1966. Ancient Indian Kingship from the Religious Point of View. Leiden: Brill.

Graeber, David, and Marshall Sahlins. 2017. On Kings. Chicago, IL: HAU Books.

Gunasekara, Bandusena, ed. 1986. Tisara Sandēśaya. Colombo: S. Godage saha Sahōdarayō.

Heesterman, J. C. 1998. "The Conundrum of the King's Authority." In Kingship and Authority in South Asia, edited by J. F. Richards, 13-40. Delhi: Oxford University Press.

Holt, John Clifford. 1991. Buddha in the Crown: Avalokiteśvara in the Buddhist Traditions of Sri Lanka. New York: Oxford University Press.

Inden, Roland. 1985a. "Lordship and Caste in Hindu Discourse." In Indian Religion, edited by Richard Burghart and Audrey Cantile, 159-79. London: Curzon Press.

_ 1985b. "The Temple and the Hindu Chain of Being." In L'Espace Du Temple I: Espaces, Itinéraires, Médiations, by Jean-Claude Galey, 53-73. Paris: École des Hautes Études en Sciences Sociales.

_. 1990. Imagining India. Cambridge, Mass.: Blackwell Publishers.

1998. "Ritual, Authority, and Cyclic Time in Hindu Kingship." In Kingship and Authority in South Asia, edited by J. F. Richards, 41-91. Delhi: Oxford University Press.

Kövecses, Zoltán. 2015. Where Metaphors Come from: Reconsidering Context in Metaphor. Oxford: Oxford University Press.

Lakoff, George, and Mark Johnson. 1980. Metaphors We Live By. Chicago: The University of Chicago Press.

Liyanarachchi, R. A., ed. 2007. Padagatārtha Sahita Mayura Sandēśaya. Colombo: Samayawardhana Publishers.

Nicholas, C. W., and S. Paranavitana. 1961. A Concise History of Ceylon: From the Earliest Times to the Arrival of the Portuguese in 1505. Colombo: Ceylon University Press.

Paranavitana, Senarath, ed. 1933. Epigraphia Zeylanica. Vol. 3. London: Oxford University Press.

Pathmanathan, S. 1982. "Kingship in Sri Lanka: A.D. 1070-1270." Sri Lanka Journal of the Humanities 8: 120-45.

Perera, Lakshman S. 2003. The Institutions of Ancient Ceylon from Inscriptions (from 831 to 1016 $A D)$. Vol. 2. 1. Kandy: International Centre for Ethnic Studies. 
Perera, P. S. (1906) 2009. Kokila Sandeśaya. Colombo: S. Godage and Brothers.

Pollock, Sheldon. 2004. "The Transformation of Culture-Power in Indo-Europe, 1000-1300." Medieval Encounters 10 (1 -3): 247-78.

- 2006. The Language of the Gods in the World of Men: Sanskrit, Culture, and Power in Premodern India. Berkeley: University of California Press.

Sax, William. 2000. "Conquering the Quarters: Religion and Politics in Hinduism." International Journal of Hindu Studies 4 (1): 39-60.

Scharfe, Hartmut. 1989. The State in Indian Tradition. Leiden: Brill.

Seneviratne, H. L. 1978. Rituals of the Kandyan State. Cambridge: Cambridge University Press. Shulman, David Dean. 1985. The King and the Clown in South Indian Myth and Poetry. Princeton, NJ: Princeton University Press.

Smith, David. 1985. Ratnākara's Haravijaya: An Introduction to the Sanskrit Court Epic. Delhi: Oxford University Press.

Spencer, George W. 1983. The Politics of Expansion: The Chola Conquest of Sri Lanka and Sri Vijaya. Madras: New Era Publications.

Tambiah, Stanley J. 1976. World Conqueror and World Renouncer: A Study of Buddhism and Polity in Thailand Against a Historical Background. Cambridge: Cambridge University Press.

Tennekoon, Rä, ed. 1955. Sävul Sandēśaya. Colombo: M.D. Gunasena.

Thompson, Ashley. 2016. Engendering the Buddhist State: Territory, Sovereignty, and Difference in the Inventions of Angkor. London: Routledge.

Veluthat, Kesavan. 2009. The Early Medieval in South India. New Delhi: Oxford University Press.

Wickremasinghe, Don Martino de Zilva, ed. 1912. Epigraphia Zeylanica. Vol. 1. London: Oxford University Press.

. 1928. Epigraphia Zeylanica. Vol. 2. London: Oxford University Press. 